\title{
ДНІПРОПЕТРОВЩИНА В РОКИ ДРУГОЇ СВІТОВОЇ ВІЙНИ В НІМЕЦЬКІЙ МЕМУАРИСТИЦІ ТА ІСТОРІОГРАФІЇ
}

\begin{abstract}
Мицик Ю. А. Дніпропетровщина в роки Другої світової війни в німецькій мемуаристиці та історіографіп.

У статті розглянуто тему відображення м. Дніпропетровська та Дніпропетровщини за часів Другої світової війни у німецькій мемуаристищі та історіографії. Автор відзначає, що Дніпропетровщина мало представлена в такого роду літературі через те, що на ії теренах не відбувалося тривалих чи жорстких оборонних боїв та битв. У німецькій історіографії та мемуаристиці Дніпропетровщцна представлена фрагментарно. 3 моменту нападу німецьких військ на СРСР Дніпропетровськ стояв на шляху слідування армії «Південь». Початковий етап боїв за Дніпропетровськ подано в німецьких мемуаристів як час численних людських та технічних втрат. Опинившись у глибокому тилу німецьких військ, Дніпропетровськ перетворився на важливий економічний центр окупованих територій. Увага мемуаристів до тилового міста значно послаблюсться. Згадки знов активізуються на етапі наступу Радянської армії та боїв за звільнення міста.

Ключові слова: мемуари, історіографія, Друга світова війна, Дніпропетровськ, нацистська окупація.
\end{abstract}

Мицик Ю. А. Днепропетровщина в годы Второй мировой войны в немецкой мемуаристике и историографии.

В статье рассмотрена тема отражения г. Днепропетровска и Днепропетровской области в период Второй мировой войны в немецкой мемуаристике и историографии. Автор отмечает, что Днепропетровщина мало представлена в такого рода литературе, поскольку на ее территории не происходило длительных или жестких оборонительных боев и поворотных сражений. С момента нападения немецких войск на СССР Днепропетровск стоял на пути следования армии «Юг». Начальный этап боев за Днепропетровск представлен у немецких мемуаристов как время больших человеческих и технических потерь. Оказавшись в глубоком тылу немецких войск, Днепропетровск превратился в важный экономический центр оккупированных территорий. Внимание мемуаристов к тыловому городу значительно ослабевает. Упоминания о Днепропетровске активизировались во время наступления Советской армии и боев за освобождение города.

Ключевые слова: мемуары, историография, Вторая мировая война, Днепропетровск, нацистская оккупация.

Mytsyk Y. A. Region Dnipropetrowsk während des Zweiten Weltkriegs in deutschen Memoiren und Geschichtsschreỉbungen.

Der Artikel analysiert der Reflexion von Dmipropetrowsk und Dmipropetrowsk während des Zweiten Weltkriegs in deutschen Memoiren und Geschichtsschreibungen. Der Autor stellt fest, dass die Region Dnipropetrowsk in dieser Art von Literatur schlecht vertreten ist, da es auf ihrem Territorium keine langen oder harten Verteidigungskämpfe und keine Wendekämpfe gab. In der deutschen Geschichtsschreibung und Memoiristik ist die Region Dnipropetrowsk fragmentarisch vertreten. Seit dem Angriff deutscher Truppen auf die UdSSR steht Dmpropetrowsk der Armee „Süd“ im Weg. Die Anfangsphase der Kämpfe um Dnipropetrowsk wird von deutschen Memoirenschreibern als eme Zeit großer menschlicher und technischer Verluste dargestellt.Die toten deutschen Soldaten wurden auf eimem Friedhof in der Nähe des Bahnhofs beigesetzt. Auf dem Friedhof wurde ein Adler-förmiges Denkmal errichtet. In den 1960-er Jahren wurde der Friedhof zerstört. Memoirenschreiber bemerken, dass zu Beginn der Besetzung der Stadt die Hauptaufgabe darin bestand, die Kommunikation zwischen dem linken und rechten Ufer der Stadt entlang des Dnipro wiederherzustellen. Da die Brücken von den sich zurückziehenden sowjetischen Truppen abgerissen wurden, musste die Pontonbrücke repariert und die Kommunikation darüber hergestellt werden. Nach der Besetzung stürzte sich Dnipropetrowsk in ein «friedliches Leben» und Memoirenschreiber zeigen em gemessenes Leben: Kinos und Bibliotheken waren funktioniert. Zu dieser Zeit wurde die Stadt von Hans-Ulrich Rudel besucht (dem besten Bomberpiloten des Zweiten Weltkriegs, Stalins persönlichem Feind). Hier stand er im Konflikt mit emem zukünftigen Memoirenschreiber. Dmpropetrowsk machte einen positiven Eindruck auf ihn. Dniprope-

(C) Ю. А. Мицик, 2020 
trowsk befand sich im tiefen Rücken der deutschen Truppen und wurde zu einem wichtigen Wirtschaftszentrum der besetzten Gebiete. Die Aufmerksamkeit der Memoirenschreiber für die Hinterstadt fällt. Die Erwähnung von Dnipropetrowsk wird während der Offensive der sowjetischen Armee und der Kämpfe um die Befreiung der Stadt verstärkt.

Schlüsselwörter: Memoiren, Geschichtsschreibung, Zweiter Weltkrieg, Dmipropetrowsk.

Mytsyk Y. A. Dnipropetrovsk region during the Second World War in German memoirs and historiography.

The article is devoted to the reflection of Dmpropetrovsk and Dnipropetrovsk region during the Second World War in German memoirs and historiography. The author notes that Dnipropetrovsk region is poorly represented in this kind of literature due to the fact that there were no long or fierce defensive battles on its territory, and there were no turning points. Therefore, in German historiography and memoirs Dnipropetrovsk region is presented only in fragments. Since the attack of German troops on the USSR, Dmpropetrovsk had been on the way of the "South" army group. The initial stage of the battles for Dmpropetrovsk is represented by German memoirists, sometimes with serious human and technical losses. The dead German soldiers were buried at a cemetery near the train station. An eagle-shaped monument was erected at the beginning of the occupation of the city. The main task of the Germans was to restore the connection between the left and right banks of the city on the Dnipro River. Since the bridges had been blown up by retreating Soviet troops, the pontoon bridge had to be repaired so that communication could be established. After the occupation Dnipropetrovsk plunged into a "peaceful life" and memoirists depict a secluded life: there were cinemas, libraries. At that time the city was visited by Hans-Ulrich Rudel, the best bomber pilot of the Second World War, Stalin's personal enemy. There he had a clash with one of the future memoirists. Dnipropetrovsk made a good impression on him. Once in the deep rear of German troops, Dnipropetrovsk turned into an important economic center of the occupied territories. So that the attention of the memoirists to the rear city is significantly reduced. The mentions of Dnipropetrovsk again increased during the Soviet offensive and the battles for the liberation of the city and the region by the Soviet army.

Key words: memoirs, historiography, the Second World War, Dnipropetrovsk, Nazi occupation.

У величезній німецькій історіографії Другої світової війни Дніпропетровській області приділяно мало уваги. Це пояснюється тим, що на території не було потужних битв, які сильно впливали на хід війни подібно Сталінградській, Курській, КорсуньШевченківській та іншим, довго не тривала оборона міста подібно Одесі, а і1і територія не була партизанським краєм (останнє пов'язується насамперед 3 географічними умовами). У тих же працях, де порушувалася ця проблемм, зазвичай недостатньо використовувалися мемуари солдат і офіцерів гітлерівської армії. В останніх, попри зрозумілу тенденційність, можна знайти чимало важливих фактів.

Отже, 22 червня 1941 р. розпочався новий етап в історії Другої світової війни гітлерівська Німеччина напала на свого союзника СРСР. У книзі істориків А. Драбкіна та О. Ісаєва «22 червня чорний день календаря» наводяться уривки із спогадів студента Дніпропетровського медичного іпституту I. Л. Друяна стосовно звістки про початок війни [3, с. 52]. Згідно з планом «Барбароса», наступ на Україну вела група армій «Південь», якою командував генерал-фельдмаршал Герд фон Рунштедт. Наступ на Дніпропетровськ вів 3-й танковий корпус, який входив до складу 1-ї танкової групи генерал-полковника Евальда фон Кляйста. Безпосередньо Дніпропетровськ брала 14-та танкова дивізія генерал-майора фон Прітвіц унд Гаффрона. Їі історію написав Рольф Грамс, який командував тоді 64-м мотоциклетним батальйоном дивізії. Після ліквідації «котла» під Уманню 36-й танковий полк дивізії увечері 14 серпня взяв м. Кривий Ріг, а дивізія стала переслідувати частини Радянської армії, що відходили до Дніпропетровська. Біля Олександрівки Радянська армія розпочала контрнаступ і вперше на цій ділянці фронту кинула в бій важкі 32-тонні танки. 19 серпня вона атакувала колони 40 танкового розвідувального батальйону та 103-го мотопіхотного полку, але після тривалого бою, втративши 21 танк, зокрема 16 важких, відступила. Німецько-фашистські війська теж зазнали серйозних втрат. Грамс вказує, що тільки один (4-й) дивізіон 4-го артилерійського полку втратив свого командира і дві гармати. 18 серпня німцям вдалося перерізати запорізьке шосе, шо змусило радянські війська тіснитися на одному плацдармі перед містом. 19 серпня окремі частини 14-ї дивізії стояли біля приміського села Сурсько-Литовського, а 25 числа розпочався німецький наступ на місто, і скоро вони оволоділи його головною (правобережною) частиною. Тоді ж під вогнем радянської авіації нацисти захопили наплавний міст на плотах, який мав дуже важливе значення. Два з трьох існуючих мостів (відомі 
зараз під назвами «старий» $\mathrm{i}$ «новий») були підірвані радянськими військами, відступали. Цей наплавний міст, який стояв трохи вище по Дніпру від «старого» мосту і який починався від вулиці Павлова, добре видно на фотографіях німецьких солдат. Його швидко відремонтували німецькі, угорські й італійські сапери і навіть збільшили його міцність. По ньому дивізія стала переправлятися на лівий берег (наразі Амур-Нижньодніпровський район) і там захопила плацдарм. До неї приєдналися частини 60-ї моторизованої дивізіі. Був тут і підрозділ капітана Альберта Брукса. Останній, до речі, воював перед тим у Польщі і Франції, відзначився взяттям Корсуня, був нагороджений Залізними хрестами 1-го та 2-го класу і представлений до Рицарського Хреста [6, с. 69].

Брала участь у взятті Дніпропетровська й відома 5-та моторизована дивізія СС «Вікінг», яка складалася переважно 3 добровольціввихідців 3 різних країн Свропи (бельгійці, голландці, датчани, естонці, латиші, норвежці, шведи, швейцарці, фіни, фламандці). Ще після 17 серпня 1941 г. «Вікінг» за допомогою дивізії «Пасубіо» 3 італійського експедиційного корпусу взяв Дніпродзержинськ і рушив на Дніпропетровськ. Цікаво, що радянська пропаганда тричі оголошувала про знищення дивізії «Вікінг», але це було лише фантазією пропагандистів [7, с. 96].

Варто сказати про дії німецької авіації. Ще 17 серпня бомбардувальники 4-го повітряного флоту (командувач генерал-полковник Льор) здійснювали денні й нічні напади на Дніпропетровськ. Вони ставили метою знищення вокзалу, шляхів і мостів, щоб зірвати відхід радянських військ, не дати їм закрінитися на лівому боці Дніпра й чинити перепони у форсуванні ріки німецькими військами. Хоча на той час 4-й флот втратив 44 літаки, решта його складу вступила в протиборство з радянською авіацією. У жорстокому повітряному бою німцями було збито 33 радянських літаки, переважно ДБ-3і СБ-3. 30 серпня винищувачі ланки JG3 майора Лютцова збили тисячний радянський літак, починаючи 322 червня [8, с. 65].

26 серпня німцям вдалося розширити плацдарм на лівому боці Дніпра завдяки тому, що на ньому сконцентрувалися сили шести батальйоні 14-ї дивізії. Полк «Норд» дивізії «Вікінг» теж брав участь у цих діях. 7. 09.1941 р. в ході боїв інші частини «Вікінга» форсували Дніпро і з'єдналися 3 полком «Норд» [23, c. 9]. О 20-й годині було передано спеціальне повідомлення про взяття Дніпропетровська. Біограф фон Рунштедта Гюнтер Блюментріт підкреслював важливість цісї події, хоча радянські війська ще утримували кілька плацдармів на правому березі Дніпра $[2, \mathrm{c}$. 112]. Вся лука Дніпра від Дніпропетровська до Херсона тепер перебувала в руках 1-ї танкової армії фон Кляйста [5, с. 15]. Але з 27 серпня по 10 вересня об'єднані зусилля німецьких військ (14-та танкова, 198-ма піхотна, 60-та моторизована дивізіi), однак, не могли суттсво розширити плацдарм через сильний опір радянських військ. Але тоді радянські війська відступали по всьому фронту, а бойовий дух солдат в цілому був низький. Тим не менш Грамс змушений був визнати, що втрати німецьких військ тут «були високими як ніколи» [1, с. 33].

Тіла вбитих ховали на кількох кладовищах Дніпропетровська. До православного кладовища, яке розташовувалося поблизу залізничного вокзалу (певний час на його місці був парк М. Калініиа), було під'єднано німецьку частину. Уродженець дніпропетровської Чечелівки відомий кінокритик і сценарист Леонід Череватенко (1938-2014) розповідав автору цих рядків, що на цій частині кладовища було встановлено й пам'ятник - фігуру орла. Я можу додати, що восени 1959 чи 1960 pp. могили німецьких солдат було знищено, а учні СШІ № 83 (в роки німецької окупації у цій шшколі стояла італійська частина) бігали туди, бо пішла чутка, що там знайшли зброю. Бігав туди і я, але ніякої, зброї, звичайно там не було; бульдозерами розривали могили й виднілися вкриті слизом кістяки й черепи, зотлілі рештки одягу й побіт.

За три місяці війни німецько-фашистські війська втратили чимало воєнної техніки. На 17 жовтня боєздатними вважалося лише 1423 338 танків і 3100 з 4300 автомобілів танкового корпусу Кляйста, а техніка була дуже зношена. На момент виходу з Дніпропетровська «частини й підрозділи вичерпали встановлений моторесурс) [12]. Генерал-майор і мемуарист Фрідріх - Вільгельм фон Мелентін відзначав у щоденнику дій 1-ї танкової групи 10-11 вересня 1941 р., що постачання артилерійськими снарядами військ, які облягали Київ, було ускладнено через велику ix витрату «на плацдармі Дніпропетровська» i вважав, що, за умови прискореного відновлення залізниць, можна підігнати ешелони постачання до Дніпра в Кременчук i Дніпропетровськ. Було створено бази постачання військ у Дніпропетровську й Кривому Розі (остання для забезпечення дивізій, які діяли на плацдармі), а також угорського та італійського корпусів [16]. 
11 вересня 14-та дивізія виступила до мосту через Днінро в районі с. Деріївки. Наступного дня вона перейшла на лівий берег ріки і рушила на Миргород, а 315 числа брала участь в оточенні Києва. Полк «Германія» дивізії «Вікінг» брав участь у боях за Кременчук, але в цілому «Вікінг» продовжив наступ по теренах Дніпропетровщини, на початку жовтня взяв Павлоград i продовжив свій шлях на Ростов-на-Дону і Кавказ. У роботі Вільгельма Тіке детальніше розповідається про шлях фінського батальйону (командувач гауптштурмфюрер Коллані) дивізії «Вікінг». Після боїв за Дніпродзержинськ i Дніпропетровськ він став у казармі, облаштованій у приміщеннях музею революції в Дніпропетровську. Тут фіни побачили картину «Вступление Красной Армии в Выборг», яка нагадувала про радянсько-фінську війну 1939-1940 pp. Вона викликала у солдатів лють, i вони тут же розбили гіпсову статую Сталіна. Оскільки транспорт батальйону, особливо 2-ї роти, був зношений, то частину його відправили на один із дніпропетровських заводів. 28 грудня 1941 р. батальйон отримав наказ іти на Сталіно (нині - Донецьк) і вирушив у похід (Дніпропетровськ - Новомосковськ Знам'янка), взяв Павлоград, а потім продовжив шлях (Петропавлівка - Слов'янка) [14, c. 90-93].

Трохи доповнюють картину подій на сході Дніпропетровщини спогади радиста «Вікінга» Гюбнера Фляйшмана. За його словами, після взяття Кременчука він був включений в ударну групу у складі 320 вояків, також 20 вантажівок, 5 БТР і 5 танків, було наказано виступати до Павлограда, який уже захопили німці. Десь на нів-дорозі вони вступили в незначну перестрілку, але потім потрапили під радянський авіаналіт і дісталися до мети із втратами. Довкола Павлограду стояли 88-ма і 102-га дивізії. Вояків здивувало те, що місцеві мешканці поводили себя так, ніби ніякої війни не було. Взвод Фляйшмана розташувався у старому шкільному будинку. Тут вони були на перепочинку три тижні. У жовтні (15.10.1941р.) ударну групу розділили між 1-м полком дивізії СC «Адольф Гітлер» та 3-м полком дивізії СС «Мертва голова». Фляйшман був переведений генерал-полковником Германом Готом до танкових частин i разом 3 ними вирушив з Павлограда на Харків $[18$, c. $195-196]$.

Період німецько-фашистської окупації вивчений явно недостатньо. Тут варто підкреслити значення німецьких фотоматеріалів. Їх досить багато, бо для німецьких вояків, на відміну від радянських, фотоапарат був легкодоступним, і вони охоче ним користувалися. Часом в Інтернеті трапляються цікаві фотографії Дніпропетровська 1941-1943 pp., зокрема залізничного вокзалу, мостів через Дніпро, центральних вулиць, православних храмів, мешканців міста... У монографії-альбомі історика Вальтера Бінерта міститься чимало фотографій, зроблених солдатами в Україні. Серед них є й такі, що стосуються Дніпропетровська: три фотографії Свято-Троїцького собору (вид ззовні і всередині), частково зруйнованого Свято-Покровського храму, який стояв на площі Островського, будинку НКВC (помилково сказано, що віи розташованифй у Запоріжжі), безіменне німецьке солдатське кладовище (можливо, це вищезгадане кладовище біля вокзалу) $[24$, с. $43,45,90,91$, 99]. Після цього зацікавленість мемуаристів Дніпропетровськом послабилося.

Місто на Дніпрі відігравало важливу роль як потужний залізничний вузол i промисловий центр, воно був важливим осередком реабілітації поранених військових. Було створено умови для відпочинку солдат, які перебували в місті для перегрупування. У місті діяло чотири кінотеатри. Матір мого шкільного товариша працювала білетером в одному 3 таких кінотеатрів. 3 ii розповідей запам'яталося небагато, зокрема те, що фільми були переважно німецькі, а серед них вирізнялися, на ii думку, фільми з Марікою Рьок і стрічка 1942 р. «Золоте місто» («Die goldene Stadt»). В одному 3 кінотеатрів побував майбутній мемуарист Віллі Кубек. У своєму щоденнику він відзначив прибуття поїздом в Дніпропетровськ 1 жовтня та 7 листопада 1942 p. (Кубек їхав з фронту в місячну відпустку й назад). На зворотному шляху він зупинився в готелі, який був за три кілометри від вокзалу. Після цього він пішов у кіно на стрічку «Що трапилось цієї ночі». Другого дня він дивився фільм «Бал». На початку січня 1943 р. він знову побував у Дніпропетровську і зупинявся в польовому шпиталі $2 / 529$ [4, с. 130,131 , $201,203]$. В одному такому кінотеатрі побував Ганс-Ульріх Рудель - найкращий пілотбомбардувальник Другої світової війни, особистий ворог Сталіна. Тут він конфліктував 3 одним майбутнім мемуаристом. У 1943 p. після Курської битви Рудель опинився на дніпропетровському аеродромі, який локалізувався «дуже далеко від наших казарм у центрі міста». Йму місто сподобалося, як і Харків. Відзначав він і те, що радянські бомбардувальники й штурмовики майже щодня атакували мости на Дніпрі, щоб відрізати 
німцям шлях до відступу, але ці атаки були «без особливого успіху». Але жителі раділи цим нальотам, вони кидались до Дніпра з корзинами задля вилову оглушеної риби. Потім його авіабаза була переміщена на 120 км на захід. Після визволення Дніпропетровська Рудель воював у небі над Кривим Рогом та П'ятихатками, вилітав на завдання між Кременчуком і Дніпропетровськом [13, с. 105, 109].

Був у Дніпропетровську i гауптман Гельмут Ліпферт - один 3 кращих асіввинищувачів люфтвафе (збив 203 радянських літаки). Ще коли він перелітав на фронт, то збився $з$ шляху і дивом потрапив у небо над Дніпропетровськом, а потім впевнено довів літак до Запоріжжя. У 1943 р. при відступі німецьких військ Ліпферт знову опинився в Україні, був поблизу Дніпропетровська в селах Новозапоріжжя і Федорівка. Вісім збитих Ліпфертом радянських літаків спіткала лиха доля на Дніпропетровщині: над Юр'ївкою (північніше Павлограда), поблизу Мишуриного Рогу, над П'ятихатками та Верхньодніпровськом $[9$, с. 75$]$.

Відвідав Дніпропетровськ і найкращий винищувач Другої світової війни Еріх Хартман («Бубі»), який у 1943-1945 рр. Збив 352 літаки. Інший пілот його ланки - Гюнтер Ралль (275 перемог) теж літав у небі над Дніпропетровщиною. Його ланка JG-52 перебувала 314 по 18 серпня 1943 р. у Перещепиному, з 8 по15 листопада 1943 р. у Дніпропетровську, а 311 листопада 1943 р. по 6 січня 1944 р. - в Апостоловому [15].

При відступі німецьких військ у 1943 p. Дніпропетровськ знову привертає увагу мемуаристів. Історик Франц Куровськи відзначав, що 5-й авіакорпус розтапував частину своїх підрозділів на аеродромі Кривого Рогу. Радянські війська прорвали фронт між Дніпропетровськом і Кременчуком, вбили клин між 1-ю танковою армією та 8-ю армісю й досягнули лінії північніше Кривого Рогу. 4-й повітряний флот кинув у бій всі авіачастини, зробив спроби розбомбити мости через Дніпро між Кременчуком i Дніпропетровськом, але безуспішно. Він брав участь у боях в районі Кривий Ріг Нікополь - Кременчук - Кіровоград. Невдалий у цілому результат цих боїв призвів до перестановок у складі командування: 13 жовтня 4-й авіакорпус перейшов під командування генерал-лейтенанта Майстера $[8$, с. 56, 300].

Білыше даних знаходимо щодо дій наземних військ. Той же Куровськи вказував, що у Дніпропетровську була 2-га рота 5-та танкового батальйону СС, частина танкового аса - ун- тершурмфюрера Карла Ніколусі-Лека. Тоді, у червні 1942 р., цей батальйон залізницею дістався зі Львова до Дніпропетровська, а потім рушив на фронт у районі Ростова-наДону [7, с. 99]. Полководець № 1 Гітлера Epix фон Манштейн, аналізуючи причини поразки німецько-фашистської армії під Сталінградом, зокрема вказував на те, що вся група армій «А», а також 4-та танкова армія, 6-та армія, 3-тя румунська та 4-та італійська армії постачалися через єдиний шлях через Дніпро - «на залізничний міст у Дніпропетровську». Цей міст обороняла 7-а зенітна дивізія $[19$, с. 349,469$]$. Генерал Фрідо фон Зенгер розповідав у своїх спогадах про відступ 17-ї танкової дивізії після поразки гітлерівської армії під Сталінградом. 23 лютого вона стала в районі Петропавлівки, де було створено плацдарм, обернений на північ, і обережно увійшіла в Петропавлівку. Німці знали, що радянські війська продовжують наступ на Дніпропетровськ, загрожуючи їнім можливим шляхам відступу. У донесеннях говорилося, що вже 11 лютого радянські війська підійшли до залізничної лінії Харків Дніпропетровськ і перерізали іi. Потім - низка боїв у верхів'ях Самари [22, с. 141] і тільки контрнаступ німців і взяття ними Харкова дали їм сподіваний перепочинок.

Картину цих подій доповнюють спогади солдатів. Ернст Бартман 3 2-ої танкового полку СС згадував, що втримати Харків під час наступу радянських військ після сталінградського «котла» було неможливо і 14 лютого танкова дивізія «Райх» відступила. «3 небаченою силою противник (радянська армія - Ю.М.) продовжував просуватися на південь до Дніпропетровська... до Павлограда і Новомосковська». Але гітлерівці спільними зусиллями дивізій «Мертва голова», «Дас Райх» і «Адольф Гітлер» зупинили цей наступ, а силами інших дивізій, які пройшли дугою північніше Новомосковська і Перещепино оточили радянські війська. Мартин Штайер, командир танка 1-ї роти танкового полку дивізії «Мертва голова», описав бої 22 лютого, що точилися між Орількою та Самарою біля с. Вербки. Дивізія «Дас Райх» повернула на північ і за підтримки бомбардувальників форсувала Самару під Павлоградом і зайняла Вербки. Тут відбулося з'єднання дивізій «Мертва голова» i «Дас Райх», а група генерал-лейтенанта М. Попова потрапила в оточення. Німці захопили Лозову, с. Веселе Павлоградського р-ну та інші населені пункти Дніпропетровської та Харківської областей і врешті захопили Харків, де бої тривали 11-14 березня 1943 р. 
$[17$, с. $15,22,24-27]$. У вересні 1943 р. 4-та танкова армія відступала на захід через Прилуки до Дніпра, а 1-ша танкова армія - до Дніпропетровська [20, с. 281].

Ріка Дніпро тимчасово затримала радянський наступ. Ще на початку 1943 р. група армій, передчуваючи новий наступ, почала зміцнювати передмостові Києва, Кременчука, Дніпропетровська й Запоріжжя. Дніпропетровськ та його околиці мав боронити 30-й армійський корпус у складі чотирьох піхотних дивізій (15-ї (генерал-лейтенант Бушенхаген), 387-ї та 46-ї (генерал-лейтенант Рьопке), 257-ї (генерал-лейтенант Пюхлер, потім генерал-лейтенант фон Бехтольсхайм). Потім три з них, за винятком 257-ї, замінили дивізії 30-го армійського корпусу: 304-та (генерал-лейтенант Зілер), 306-та (генерал-лейтенант Кьолер), 62-а (генерал-майор Троннір) у складі 1-ї танкової армії (генерала-полковника Хубе). ІІх ослабленим силам довелося боронити широку ділянку фронту, до того ж Дніпро був помережаний островами, а саме місто 3 його населенням серйозно тривожило німців: «ще більшу загрозу являло значне місто Дніпропетровськ, яке 3 труднощами вдавалося утримувати під контролем» [21, c. 153].

Радянський наступ у жовтні 1943 p. привів до успішного форсування Дніпра на плацдармі Військове - Вовніги. Майже одночасно війська 2-го Українського фронту у складі пести армій прорвали німецький фронт між 8-ю армією і лівим крилом 10-ї танкової армії генерала Хубе та повели наступ на Кривий Ріг - центр постачання й комунікацій групи армій «Південь». У Кривому Розі розміщувалися запаси спорядження і боєприпасів для всього регіону. Там стояло багато паровозів і вагонний парк, необхідний для нормального функщіонування групи армій «Південь». Фельдмаршал Манштейн не міг допустити такої втрати. Він зібрав шість ослаблених танкових дивізій, включаючи сумнозвісну дивізію СС «Мертва голова», i завдав контрудару. Радянські війська втратили понад 300 танків, чимало вбитими, а близько 5000 душ потрапило в полон, після чого вони відступили до Дніпра. Це дозволило Манштейну хоча б тимчасово стабілізувати фронт [10, с. 131-132].

Тоді ж розгорнулися тяжкі бої за Нікополь. Німеччина дуже хотіла втримати цей район багатий покладами марганщю. Як писав Манпттейн, утримання Нікополя Гітлер вважав «винятково важливим», а його «втрата... означала б кінець війни» $[19$, с. 515,584$]$. У листопаді 1943 р. їм вдалося ціною великих втрат зберегти за собою контроль над районом. Однак новий наступ радянських військ силами 10 дивізій призвів до знищення майже всієї 3-ї гірничо-стрілкової дивізії. 30.01.1944 р. при впадінні у Дніпро р. Базавлук дві німецькі армії опинилися під загрозою оточення. 12 лютого 1944 р. розпочався загальний відступ 3 Нікопольського плацдарму. Тільки ціною великих втрат 3-тя гірничо-стрілкова дивізія вирвалася з оточення і прибула до нової лінії німецького фронту біля міста Інгулець (нині - у складі Кривого Рогу). Але й тут тривала протягом шести днів тяжка битва, в якій брали участь 3-тя і 16-та танково-гренадерські дивізії. 6 березня 1944 p. радянська армія оволоділа Інгульцем [11, c. 83-85, 91, 105]. Далі радянські війська продовжили свій переможній наступ на захід, а Дніпропетровськ лишився у глибокому тилу i, природно, про нього не могли вже писати німецькі мемуаристи-ветерани. Але їхні свідчення про місто у 1941-1943 рр. нерідко є унікальними і дозволяють доповнити його історію.

\section{Бібліографічні посилання}

1. Грамс Р. 14-я танковая дивизия 1940-1945. Москва, 2014. $446 \mathrm{c}$.

2. Гюнтер Блюментрит. Фельдмаршал фон Рунштедт. Войсковые операции групп армии «Юг» и «Запад». Москва, 2005. 300 c.

3. Драбкин А., Исаев А. 22 июня черный день календаря. Москва, 2008. 73 с.

4. Кубек В. Передовой отряд смерти. Фронтовой дневник разведчика вермахта 1942-1945. Москва, 2010. 256 c.

5. Куровский Ф. 500 танковых атак. Лучшие асы Панцерваффе. Москва, 2007. 384 с.

6. Куровский Ф. Немецкая мотопехота. Москва, 2006. $350 \mathrm{c}$.

7. Куровский Ф. Немецкие танковые асы. Москва, 2007.384 c.
8. Куровский Ф. Черный крест и красная звезда. Москва, $2011.350 \mathrm{c}$.

9. Липферт Г. Дневник гауптмана люфтваффе. 52-я истребительная эскадра на восточном фронте1942-1945. Москва, 2007. 227 с.

10. Манн K. SS-Totenkopf. История дивизии CC «Мертвая голова» 1940-1945. Москва, 2006. 192 с.

11. Олленберг Йозеф. Немецкий снайперна восточном фронте 1942-1945. Москва, 2008. 320 с.

12. Роберт Кершоу. Березовые кресты вместо железных. Москва, 2008. 371 с.

13. Рудель Г. Пилот «штуки». Минск, 2006. 272 c.

14. Тике В. Батальон «Нордост» в боях за Кавказ. Финские добровольцы на Восточном фронте 19411943. Москва, 2015. 317 с. 
15. Толивер Р.Ф. Констебль Т.Д. 352 победы в воздухе. Лучший ас Люфтваффе Эрих Хартманн. Москва, 2013. 377 c.

16. Ф. В. фон Меллентин. Танковые сражения. Боевое применение танков во второй мировой войне 1939-1945. Москва, 2006. 303 с.

17. Фей В. Танковые сражения войск СС. Москва, 2009. 413 c.

18. Фляйшман Г. По колено в крови. Откровения эсэсовца. Москва, 2009. 480 с.

19. Фон Манштейн Эрих. Утерянные победы. Воспоминания фельдмаршала. Москва, 2007. 349, 469 c.
20. Фон Меллентин Ф.В. Танковые сражения. Москва, 2006. $832 \mathrm{c}$.

21. Фреттер-Пико М. Немецкая пехота. Стратегические ошибки вермахта. Пехотные дивизии в войне против Советского Союза 1941-1944. Москва, 2013. 192 с.

22. Фридо фон Зенгер. Ни страха, ни надежды. Хроника второй мировой войны глазами немецкого генерала 1940-1945. Москва, 2004. 479 с.

23. Хоффман Т. «Викинги» Гитлера. Эсэсовский интернационал. Москва, 2011. 448 с.

24. Bienert W. Was fur Menschen sind das? Berichte, Bilder und Folgerungen aus dem Zweiten Weltkrieg. Koln, 1990. $150 \mathrm{c}$.

\section{Referances}

1. Grams R. (2014) 14-ya tankovaya diviziya 1940 1945 [14th Panzer Division 1940-1945]. Moscow (in Russian).

2. Gyunter B. (2005) Feldmarshal fon Runshtedt. Voyskovyye operatsii grupp armii «Yug» $i$ «Zapad» [Field Marshal von Runstedt. Troop operations of army groups "South" and "West"]. Moscow (in Russian).

3. Drabkin A. Isayev A. (2008) Dvadzat vtoroye iunya chernyy den kalendarya [June 22 - black calendar day]. Moscow (in Russian).

4. Kubek V. (2010) Peredovoy otryad smerti. Frontovoy dnevnik razvedchika vermakhta 1942-1945. [The vanguard of death. Front diary of a Wehrmacht scout 19421945]. Moscow (in Russian).

5. Kurovskiy F. (2007) 500 tankovykh atak. Luchshiye asy Pantservaffe. [500 tank attacks. The best aces of the Panzerwaffe]. Moscow (in Russian).

6. Kurovskiy F. (2006) Nemetskaya motopekhota. [German motorized infantry]. Moscow (in Russian).

7. Kurovskiy F. (2007) Nemetskiye tankovyye asy. [German tank aces]. Moscow (in Russian).

8. Kurovskiy F. (2011) Chernyy krest i krasnaya zvezda. [Black cross and red star]. Moscow (in Russian).

9. Lipfert G. (2007) Dnevnik gauptmana lyuftvaffe. 52 ya istrebitelnaya eskadra na vostochnom fronte1942-1945. [Diary of a Luftwaffe Hauptmann. 52nd Fighter Squadron on the Eastern Front]. Moscow (in Russian).

10. Mann K. (2006) SS-Totenkopf. Istoriya divizii SS "Mertvaya golova» 1940-1945 [SS-Totenkopf. History of the SS Division "Death's Head" 1940-1945]. Moscow (in Russian).

11. Ollenberg Yozef (2008) Nemetskiy snayperna vostochnom fronte 1942-1945 [German sinper on the eastern front 1942-1945]. Moscow (in Russian).

12. Robert Kershou (2008) Berezovyye kresty vmesto zheleznykh [Birch crosses instead of iron ones]. Moscow, (in Russian).

13. Rudel G. (2006) Pilot «shtuki» [The pilot of the "piece"]. Minsk (in Russian).
14. Tike V. (2015) Batalon «Nordost» v boyakh za Kavkaz. Finskiye dobrovoltsy na Vostochnom fronte 19411943. [Battalion "Nordost" in the battles for the Caucasus. Finnish volunteers on the Eastern Front 1941-1943]. Moscow (in Russian).

15. Toliver R.F. (2013) Konstebl T. D. 352 pobedy $v$ vozdukhe. Luchshiy as Lyuftvaffe Erikh Khartmann [Constable T. D. 352 victories in the air. The best ace of the Luftwaffe is Erich Hartmann]. Moscow (in Russian).

16. F. V. fon Mellentin (2006) Tankovyye srazheniya. Boyevoye primeneniye tankov vo vtoroy mirovoy voyne 1939-1945 [Tank battles. Combat use of tanks in World War II 1939-1945]. Moscow (in Russian).

17. Fey V. (2009) Tankovyye srazheniya voysk SS [Tank battles of the SS troops]. Moscow (in Russian).

18. Flyayshman G. (2009) Po koleno v krovi. Otkroveniya esesovtsa [Knee-deep in blood. SS man's revelations]. Moscow (in Russian).

19. Fon Manshteyn Erikh (2007) Uteryannyye pobedy. Vospominaniya feldmarshala [Lost victories. Memories of a field marshal]. Moscow, (in Russian).

20. Fon Mellentin F.V. (2006) Tankovyye srazheniya [Tank battles]. Moscow (in Russian).

21. Fretter-Piko M. (2013) Nemetskaya pekhota. Strategicheskiye oshibki vermakhta. Pekhotnyye divizii v voyne protiv Sovetskogo Soynza 1941-1944. [German infantry. Strategic mistakes of the Wehrmacht. Infantry divisions in the war against the Soviet Union 1941-1944]. Moscow (in Russian).

22. Frido fon Zenger (2004) Ni strakha. ni nadezhdy. Khronika vtoroy mirovoy voyny glazami nemetskogo generala 1940-1945 [No fear, no hope. Chronicle of World War II through the eyes of a German general 1940-1945]. Moscow (in Russian).

23. Khoffman T. (2011) "Vikingi» Gitlera. Esesovskiy internatsional [Hitler's Vikings. SS International]. Moscow (in Russian).

24. Bienert W. (1990) Was fur Menschen sind das? Berichte. Bilder und Folgerungen aus dem Zweiten Weltkrieg. Koln (in German). 